\title{
How Charles Darwin's Early Years Led Him to Revolutionize Biological Thought
}

\author{
The Young Charles Darwin by Keith Thomson. New Haven \& London: Yale University \\ Press, 2009, Pp. xii + 276, \$28.00
}

\author{
Joel S. Schwartz
}

Published online: 29 July 2009

(C) Springer Science + Business Media, LLC 2009

Celebration of the bicentenary of Charles Darwin's birth, as well as the sesquicentenary of publication of his On The Origin of Species, has been marked by many studies of almost every aspect of his life and contributions. Many books already have been published this year, and two definitive biographies of Darwin were published a decade ago: Janet Browne's two volume work, Voyaging (1995) and The Power of Place (2002) and Adrian Desmond and James Moore's Darwin: The Life of a Tormented Evolutionist (1991), along with the publication of numerous other biographies. New editions of On the Origin of Species and The Voyage of the Beagle have been published-glossy illustrated works that make these books come alive for the more casual reader. In addition, the Darwin Correspondence Project is thriving, making his correspondence accessible to many scholars and other interested parties who wish to learn more about him, and new volumes are being published every year; eventually, his entire correspondence will be in print. His notebooks were published some time ago, and a new project also promises to make all his notes, his marginalia in his books etc., available to those interested not just in Darwin but the entire subject of evolution and modern natural history.

Keith Thomson's The Young Charles Darwin is further demonstration that the thriving Darwin industry is alive and well. In his introduction, he dutifully pays homage to both Browne and Desmond and Moore's earlier contributions, indicating that his purpose "is not to retell the story of

J. S. Schwartz $(\square)$

Professor Emeritus, College of Staten Island, CUNY,

118 82nd Drive, Kew Gardens,

NY 11415, USA

e-mail: joels.schwartz@earthlink.net
Charles Darwin's life, which has already been done superbly well by (leading all others) Janet Browne, Adrian Desmond, and James Moore" (p. viii). He indicates that he wishes to explore the way in which the forces, particularly in Darwin's early life, shaped his ideas, so the reader will better understand that the theory of natural selection did not come out of the "clear blue sky." To help meet this goal, Thomson has employed a vast array of published material, largely taken from Darwin's Autobiography written in 1876, less than a decade before his death, to fulfill a request from his children to write a personal account of his life; also from correspondence during his earlier years, published by the Darwin Correspondence Project; his published notebooks; and the work of other biographers. He has integrated this material quite well, and the result is an interesting account of not just Darwin's youth but also his voyage on H.M.S. Beagle and his life afterwards when Darwin settled down to the life of a country squire, experimenting on a wide variety of subjects and pondering the question of how species were formed and transmutated.

Since Thomson is primarily a naturalist with many published scientific papers to his credit, his work promised to be a fresh approach to a well-explored subject told from a different perspective. It is a very readable book, offering a different look at information that has become familiar to those involved in the history of ideas. However, despite Thomson's skill, the book is somewhat disappointing in that what he offers as new often turns out to be conjecture. He often takes a quotation from Darwin's Autobiography or his letters out of context and then makes assertions that are primarily "leaps of faith" and occasionally contradictory. The effect is that Darwin and other individuals in this account have been diminished, and whether or not this was deliberate to avoid writing another hagiographic account of Darwin's life, some of his attempts to puncture the previous 
glowing accounts of Darwin's life and works seem to be forced. Moreover, after reading Browne's two-part biography as well as Desmond and Moore's work and their recently published, Darwin's Sacred Cause, my question is why another work containing much of the same material was necessary. The first volume of Browne's work, Voyaging, seems to cover Darwin's early life quite thoroughly and comprehensively and, of course, includes a lengthy description of his voyage and the effect it had on his life and career.

Thomson's approach to his subject is immediately apparent when he discusses Darwin's return from his voyage to England in the introductory chapter, with claims that Darwin "had jumped ship" (p. 4). The author directs the reader to a letter Darwin wrote to his Captain, Robert Fitzroy-on October 6, 1836-characterizing it as an apology. Upon reading the letter, written a few days after Darwin left the ship after it berthed in Falmouth before heading to Plymouth, one discovers that it is not so much an apology but as an explanation that he was not well and was not up to additional wear on his fragile constitution. The letter is primarily devoted to other topics, and it seems that Thomson has made more of this episode than anyone else and has "jumped" to the wrong conclusion. He does report that Darwin traveled to Plymouth afterwards to see his old shipmates off before they embarked on another journey. Thomson would want to leave the reader with the impression that it may have been guilt over his "jumping ship" that motivated Darwin to visit with his old mates, but given the difficulty Darwin had on ships sailing even on relatively open water-well chronicled in many accounts of Darwin's life - can he be blamed for wanting to not submit to more jostling and tossing about on the ship he had faithfully traveled on for over five years? Darwin's seasickness and other maladies have been a topic that many scholars have puzzled over for quite some time, but Thomson rather cavalierly labels Darwin as a lifelong "hypochondriac" (p. 29).

Darwin's family members are not spared either. Thomson describes them in detail as well as the influence they had on Darwin, portraying Darwin's illustrious grandfather, Erasmus Darwin, as a "dark, stern man, sarcastic, with a violent anger" (p. 16). Is this the same Erasmus Darwin, who was a member of the Lunar Society and friend and associate of Benjamin Franklin and other luminaries, the author of "The Temple of Nature" and other poems, some containing early evolutionary models, as well as an accomplished scientist and thinker in his own right, and a product of the Enlightenment? Although many of the author's statements have been documented with excellent footnotes, his characterization of Erasmus Darwin stands out boldly, but this particular statement is not well supported. Previous biographical accounts of Erasmus Darwin's life have indicated that he was a complex man with many faults along with his virtues, but the author suggests that he was some sort of monster.

To make certain that the idea that the Darwins were rather unpleasant becomes fixed in the reader's mind, Thomson describes Darwin's father, Robert Waring Darwin thusly: "Like his father, [Erasmus] he grew up very portly (to be polite). In public he had the same bonhomie, but within the family his disposition was more authoritarian than sunny. He seems very much like his father: a very unsympathetic man, bullying both his family and his patients, and excessively frugal in everything to do with money" (p.18). Again, there is little support for these charges, although the literature indicates that Darwin was intimidated by his father, and it seems he was an imposing figure to young Charles. But, in the final analysis, Robert Darwin supported his son despite Darwin's frequent changes in the direction of his career and his lack of promise, particularly in subsidizing his passage for over five years on the Beagle. As Thomson relates-although again not at length-Darwin handled his father rather well when he found his father to be dead set against the venture and cleverly enlisted his Uncle Jos (Josiah Wedgwood) to support his efforts. This episode has been captured in many accounts of Darwin's life but deserved a bit more than the author was inclined to describe. Thomson devotes little space to the other side of Darwin's family, the Wedgwoods, a truly remarkable group of individuals, whose influence on Darwin's social and political views basically are ignored by the author.

Thomson hypothesizes that Darwin needed a "mentor" at each stage of his early life (pp. 23-25 and 93-94) and was "self-absorbed and immature." Although he indicates that in his Autobiography, Darwin "revealed little of himself" (p. 25), he recognizes that when Darwin wrote it in 1876, his memory may have been cloudy. Thomson seems to rely on this work a great deal, taking what Darwin recalled quite literally, then leaping to conclusions that seem to be juxtaposed to Darwin's intentions. For example, in the Autobiography, the author notes that Darwin "dismissed" his Cambridge years, indicating his time there "was wasted" (p. 97). Darwin was not being critical of Cambridge; he was critical of himself, berating himself for not taking better advantage of his opportunity there.

Thomson seems a bit too eager to place familiar facts in the most negative terms. He describes Darwin on the Beagle as "a dashing, daring explorer, happy and confident," but in "middle age, while achieving scientific fame, he was characterized by querulousness, reclusiveness, and endless illness" (p. 27). Certainly, Darwin was afflicted with chronic illness, and he remained at Downe most of his adult life, but the charge of "querulousness" is a puzzling one. Who was responsible for characterizing Darwin in this 
manner? The author does not say, nor is this documented. A darker charge is the author's citation of an earlier and forgotten work, Edward Kempf's Psychopathology (1931), where Darwin is described as having "a morbid interest in sex" and concluded he was "a repressed homosexual" (p. 29). Thomson disputes this charge, although not very vigorously, weakly demurring that because of the number of children Darwin fathered, he did not exactly suppress his interest in sex. The more important issue is why he included such a dubious study in this discussion.

Thomson indicates that Darwin dismissed people such as the naturalist Robert Jameson at Edinburgh University because he was cold and distant to Darwin, not for the reasons Darwin recalled in his Autobiography: that his lectures were dull. He asserts that "Darwin may have been drawn to Jameson as the one man whose interests were close to his: minerals, natural history, collections, science. But Jameson lacked the warmth of personality that would allow him to cultivate the very young Darwin, and Darwin in turn lacked the strength of personality to appeal to Jameson as an independent scholar" (pp. 93, 94). Thomson admits that this is a bit of a reach but may account for Darwin's "extraordinary dismissal of Jameson and Jameson's geology in the Autobiography." $\mathrm{He}$ adds that Jameson finished his lectures by discussing species, charging that Darwin wanted to retain all the credit for his discoveries for himself, despite insisting that Darwin did not take up the question of species until quite a bit later on, beyond the time suggested by most historians of science (1838).

The author devotes a good deal of space to another "potential mentor" from Edinburgh, Edward Grant. At the age of 18, Darwin found himself working alongside Grant. Grant at first valued Darwin's contributions and observations-Thomson indicates that Grant "came alive" in Darwin's presence because he saw the spark of a real scholar in Darwin (p. 60). However, when Darwin observed the motility in the so-called ova-later discovered to be larvae-of Flustra carbacea, a primitive invertebrate (belonging to Ectoprocta), commonly called "sea-mats," Grant's "response was chilly" when Darwin attempted to show Grant his discovery (p. 67), and he appropriated Darwin's observations as his own. Darwin never forgave Grant for taking credit for his work. Grant had studied the organism and related species for some time and had published numerous papers on the subject, but he never observed motility in these cells so he might have been distressed that this young neophyte was successful in observing some phenomena he was unable to see. Grant's rather shabby treatment of Darwin, which Thomson readily admits to, is the primary reason for Darwin having "a distaste for Grant, once his respected mentor."

Thomson takes issue with Darwin's comment in his Autobiography that "Grant accomplished nothing in science when at London." He reminds readers that, "in fact, Grant did a great deal" (pp.69, 70). He suggests that Darwin had other reasons for summarily dismissing Grant; i.e., "Grant was an evolutionist" (p. 70), presumably meaning that Darwin could not tolerate any rival evolutionist, a questionable assertion that Thomson fails to support and that is not consistent with the general notions expressed about Darwin's receptivity to the ideas of other evolutionists. Unfortunately, Thomson, drops the subject, so it remains another example of the author's unwillingness to go beyond veiled suggestions and support such claims. Judging by the information provided in Thomson's account, it seems that Darwin acted in a fairly justifiable manner, considering the fact that he was still upset with Grant for taking credit for a discovery he had made.

Thomson discusses the Captain of the Beagle, Robert Fitzroy, in detail, indicating that he was a fine naturalist and that Fitzroy and Darwin were much alike because both were interested in science and both suffered from depression (p. 139). In Darwin's case, this charge is unsubstantiated. Thomson believes that Fitzroy's later suicide as well as other cases of suicide in his family is comparable to the suicide of Darwin's uncle, Erasmus. Actually, there is no documentation of Darwin's depression, and no one ever asserted that he had suicidal tendencies. The author then attempts to show how different they really were, contrary to his initial assertion. He claims that during the voyage and at the beginning, "Darwin was the more conventionally religious of the two," and "Fitzroy... was something of a freethinking agnostic" (p. 145). This notion is hardly credible, as well as his suggestion that Darwin had an unabashed admiration for Fitzroy. He admired certain of Fitzroy's general abilities and seamanship, but quite early on he was upset when he observed Fitzroy's explosive temper and irrational behavior while they were buying dinnerware and other supplies prior to the Beagle's departure and a short time afterwards, when he witnessed Fitzroy's rather merciless flogging of some Christmas revelers before the Beagle sailed. The two men disagreed sharply over questions in natural history, over such matters as explanations for the appearance of marine fossils at high elevations and also the issue of slavery and the treatment of the natives in South America, which Darwin found abhorrent and Fitzroy more than tolerated - a subject that frequently came up in their heated discussions.

Thomson neglects this important topic and how it shaped Darwin's thinking and even his science. Recently, it has been suggested elsewhere that Darwin's hatred of slavery and racial prejudice perhaps was the spark for experiments he conducted on hybridization in animals, as well as plants, and drove him to construct his evolutionary theory. There is little discussion devoted to Darwin as a researcher; e.g., how he turned portions of his home at Downe into a 
laboratory, except a comment that he did not properly acknowledge his parents' interest in pigeons. Darwin's own experiments with pigeons and barnacles are largely ignored, and it should have been made clear that rather than being diversions from his taking on the problem of species, they were very much part of his plan to tackle the question of speciation. Instead, Thomson asserts that even by 1837 when he opened his species notebook, Darwin's aims were "less defined" (p. 182).

There are a number of useful revelations in this book, such as that prior to Darwin's opportunity to serve as the unofficial naturalist aboard the Beagle, he and his mentor John Stevens Henslow planned an expedition to Tenerife in the Canary Islands. Unfortunately, as soon as the author reveals this interesting bit of information, he proceeds to diminish its significance by dismissing such talk a "pie-in-the-sky" (p. 131), a puzzling way of treating interesting and fresh information, because it suggests that Darwin's wonderful opportunity was not quite so serendipitous as previously believed.

The author's notes are very helpful, and he skillfully weaves Darwin's correspondence, notes, and his Autobiography together quite effectively. If the book had more illustrations, photographs, and maps, it would have strengthened. The most unfortunate aspect is the author's choice of words in describing Darwin and his character. The fact that this work is not a hagiography is not the problem. On the contrary, there is room for a serious discussion of Darwin's frailties; but there is little effort to substantiate the rather broad assertions that have been advanced here, so one can only speculate about the reasons for the author's less than gracious attitude toward Darwin, his ideas, and his contributions to the biological sciences. 